\title{
Conceptualizing of Rural Settlements Development
}

\author{
Azimkhan A. Satybaldin ${ }^{1}$, Aizhan T. Tleuberdinova ${ }^{1 *}$, Xeniya V. Kulik ${ }^{2}$ \\ ${ }^{1}$ Institute of Economics of the Science Committee of the Ministry of Education \\ and Science of the Republic of Kazakhstan, 29 Kurmangazy str., 050010, Almaty, Kazakhstan
}

${ }^{2}$ TURAN University, $16 a$ Satpaeva str., 050013, Almaty, Kazakhstan

\begin{abstract}
The problem of territorial development is quite relevant for countries that cause a wide range of development issues: a low level of quality of life, underdeveloped infrastructure, migration of the working-age population to urban areas, etc. countryside. Certain difficulties in the development of rural areas are currently characteristic of Kazakhstan, 41 percent of whose population lives in rural areas. In recent years, there has been a stable trend of the outflow of the rural population, mainly young people, to the cities. The main reason for this phenomenon is dissatisfaction with the living conditions in the countryside. Rural areas of the country are characterized by low incomes of the population, underdeveloped transport infrastructure, lack of many utilities, insufficient provision of social services (health, education, culture).This situation cannot but worry the country's leadership, since it has a multi-vector impact on the socio-economic development of Kazakhstan: food self-sufficiency of the country's regions, the export potential of the agricultural sector, and the balanced structure of the economy. In this connection, there is a need for a detailed solution of problems and the search for their ways, methods and mechanisms for achieving goals. According to the authors of the article, the proposed author's model can become a basis for optimal development of the country.

The authors analyzed the existing definitions of "development", "rural areas", "development of rural areas", gave their own formulation of the definition of the development of rural areas. Based on the study of foreign experience, important aspects of rural development policy have been identified, the authors have proposed mechanisms by which rural development can be implemented.

The article focuses on the importance of interaction between all stakeholders interested in the development of rural areas.

The purpose of this article is to develop the author's conceptual model for the development of rural areas based on a theoretical review of existing definitions.

The results of the research - the author's definition and the proposed conceptual model are of interest both for scientific research in this area and for practical programs for rural development.

Keywords: development, rural areas, conceptual model.
\end{abstract}

For citation: Satybaldin, A.A., Tleuberdinova, A.T. \& Kulik, X.V. (2021). Conceptualizing of Rural Settlements Development. Economics: the Strategy and Practice, 16(3), 6-21, https://doi.org/10.51176/1997-9967-2021-3-6-21

* Corresponding author: Aizhan T. Tleuberdinova - Doctor of Economic Sciences, Chief Researcher, Institute of Economics Science Committee of the Ministry of Education of the Republic of Kazakhstan, 050010, Almaty, 29 Kurmangazy str., Kazakhstan,+77014394931, e-mail: tat404@mail.ru

Conflict of interests: the authors declare that there is no conflict of interest

Financial support: This research is funded by the Science Committee of the Ministry of Education and Science of the Republic of Kazakhstan (targeted funding program IRN OR11465433 «Developing the concept and mechanisms of balanced territorial development of the economy and society of Kazakhstan»)

The article received: 07.08 .2021

The article approved for publication: 16.08. 2021

Date of publication: 30.09 .2021 


\title{
Ауылдық аумақтарды дамытуды тұжырымдау
}

\author{
Сатыбалдин Ә.Ә. ${ }^{1}$, Тлеубердинова А.Т. ${ }^{*}$, Кулик К.В. ${ }^{2}$ \\ ${ }^{1}$ Қазақсстан Республикасы Білім және вылым министрлігі Ғылым комитетінің \\ Экономика институты, Құрмангазы к., 29, 050010, Алматы қ., Қазақстан \\ ${ }^{2}$ Тұран университеті, Сатпаева д., 16а, 050013, Алматы к.., Қазақ̧стан
}

\begin{abstract}
Түйін
Мақаланың мақсаты қолданыстағы анықтамаларға теориялық шолу жүргізу негізінде ауылдық аумақтарды дамытудың авторлық тұжырымдамалық моделін әзірлеу болып табылады. Бұл құбылыстың негізгі себебі - ауылдағы өмір жағдайына қанағаттанбау. Елдің ауылдық жерлері халықтың табысының төмендігімен, көлік инфрақұрылымының дамымауымен, көптеген инженерлік желілердің жоқтығымен, әлеуметтік қызметтердің (денсаулық сақтау, білім, мәдениет) жетіспеушілігімен сипатталады. Бұл жағдай Қазақстанның әлеуметтік-экономикалық дамуына көп векторлы әсер еткендіктен ел басшылығын мазалататыны анық: ел аймақтарының азық-түлікпен өзін-өзі қамтамасыз етуі, аграрлық сектордың экспорттық әлеуеті, экономика құрылымының тепе-теңдігі. Осыған байланысты бар проблемаларды егжей -тегжейлі талдау және оларды шешу жолдарын, қойылған мақсаттарға жетудің әдістері мен механизмдерін іздеу қажеттілігі ашылады. Мақала, авторларының пікірінше, ұсынылған авторлық концептуалды модель еліміздің ауылдық жерлерін оңтайлы дамытудың негізі бола алады. Авторлар «даму», «ауылдық аумақтар», «ауылдық аудандарды дамыту» деген дефиницияларға талдау жасады, ауылдық аумақтарды дамытуды айқындаудың өзіндік тұжырымын берді. Шетелдік тәжірибені зерделеу негізінде ауылды дамыту саясатының маңызды аспектілері айқындалды, авторлар ауылды дамытуды іске асыруға болатын тетіктерді ұсынды. Мақалада ауылдық аумақтарды дамытуға мүдделі барлық тараптардың өзара іс-қимылының маңыздылығына назар аударылады.Зерттеу нәтижелері - автордың ұсынған тұжырымдамалық моделі мен анықтамасы осы саладағы ғылыми зерттеулер үшін де, ауылды дамытудың тәжірибелік бағдарламалары үшін де қызығушылық тудырады.
\end{abstract}

Түйін сөздер: даму, ауылдық аумақтар, тұжырымдамалық модель.

Дәйексөз алу үшін: Сатыбалдин Ә.Ә., Тлеубердинова А.Т., Кулик К.В. (2021). Ауылдық аумақтарды дамытуды тұжырымдау. Экономика: стратегия және практика, 16(3), 6-21, https://doi.org/10.51176/1997-9967-2021-3-6-21

* Хат-хабаршы авторы: Тлеубердинова Айжан Тохтаровна - экономика ғылымдарының докторы Қазақстан Республикасы Білім және ғылым министрлігі Ғылым комитетінің «Экономика институты» РМҚК Қазақстан 050010, Алматы, қ. Құрманғазы 29, бас ғылыми қызметкері, +77014394931, tat404@mail.ru

Мүдделер қақтығысы: авторлар мүдделер қақтығысының жоқтығын мәлімдейді.

Қаржыландыру. Зерттеуді қаржыландыру көзі-зерттеу Қазақстан Республикасы Білім және ғылым министрлігінің ғылым комитетімен бағдарламалық-мақсатты қаржыландыру шеңберінде жүргізілді (ЖТН OR11465433 «Қазақстан экономикасы мен қоғамының теңгерімді аумақтық даму Тұжырымдамасы мен тетіктерін әзірлеу»).

Мақала редакцияға түсті: 07.08.2021

Жариялау туралы шешім қабылданды: 16.08.2021

Жарияланды: 30.09 .2021 


\title{
Концептуализация развития сельских территорий
}

\author{
Сатыбалдин А.А., ${ }^{1}$ Тлеубердинова А.Т. ${ }^{*}$, Кулик К.В. ${ }^{2}$ \\ ${ }^{1}$ Институт экономики Комитета науки Министерства образования и науки Республики \\ Казахстан, ул. Курмангазы,29, 050010, г. Алматы, Казахстан \\ 2 Университет “Туран”, ул. Сатпаева 16, 050013, г. Алматы, Казахстан
}

\begin{abstract}
Аннотация
Целью данной статьи является разработка авторской концептуальной модели развития сельских территорий на основе проведения теоретического обзора существующих определений. Сельские районы страны характеризуются низким уровнем доходов населения, неразвитостью транспортной инфраструктуры, отсутствием многих коммунальных удобств, недостаточной обеспеченностью социальными услугами (здравоохранения, образования, культуры). Данная ситуация не может не волновать руководство страны, поскольку она имеет многовекторное влияние на социально-экономическое развитие Казахстана: продовольственную самообеспеченность регионов страны, экспортный потенциал аграрного сектора, сбалансированность структуры экономики. В связи с чем возникает необходимость детального анализа существующих проблем и поиск путей их решения, способов и механизмов достижения установленных целей. По мнению авторов статьи, предложенная авторская концептуальная модель может стать основой для оптимального развития сельских районов страны. Авторами проанализированы существующие дефиниции «развитие», «сельские территории», «развитие сельских районов» и дана собственная формулировка определения развития сельских территорий. На основе изучения зарубежного опыта, определены важные аспекты политики развития села, авторами предложены механизмы, с помощью которых может быть реализовано сельское развитие. В статье акцентируют внимание на важности взаимодействия всех стейкхолдеров, заинтересованных в развитии сельских территорий. Результаты исследования - авторское определение и предлагаемая концептуальная модель представляют интерес, как для научных исследований по данному направлению, так и для практических программ развития села.
\end{abstract}

Ключевые слова: развитие, сельские территории, концептуальная модель.

Для цитирования: Сатыбалдин А.А., Тлеубердинова А.Т., Кулик К.В. (2021). Концептуализация развития сельских территорий. Экономика: стратегия и практика, 16(3), 6-21, https://doi.org/10.51176/1997-9967-20213-6-21

* Корреспондирующий автор: Тлеубердинова Айжан Тохтаровна - доктор экономических наук, РГКП «Институт экономики» Комитета науки Министерства образования и науки Республики Казахстан, 050010, г. Алматы, Курмангазы 29, главный научный сотрудник, +77014394931, e-mail: tat404@mail.ru

Конфликт интересов: авторы заявляют об отсутствии конфликта интересов.

Финансирование. Источник финансирования исследования - Исследование проведено в рамках программно-целевого финансирования Комитетом науки Министерства образования и науки Республики Казахстан (ИРН OR11465433 «Разработка концепции и механизмов сбалансированного территориального развития экономики и общества Казахстана»).

Статья поступила в редакцию: 07.08 .2021

Принято решение о публикации: 16.08 .2021

Опубликовано: 130.09 .2021 


\section{Kipicne}

Ауылдық аумақтарды дамытудың ел үшін стратегиялық маңызы бар, өйткені ол азықтүлікпен қамтамасыз ету мәселесін шешуге айтарлықтай әсер етеді, бұл көбінесе жақсы басқаруға, институционалдық әлеуеттің болуына, қолданылатын саясат пен оны жүзеге асыруға байланысты. Аталған түйінді міндетті шешу бағыттарының бірі аграрлық өндірісті және елдің азық-түлікпен өзінөзі қамтамасыз етуін дамыту негізі ретінде Қазақстанның ауылдық елді мекендерін көтеру тұжырымдамасы мен тетіктерін әзірлеу болып табылады, бұл ауылдық аумақтарды дамытудың тұжырымдамалық негіздеріне шолу жасау қажеттілігін болжайды.

Еліміздің ауыл, ауылдық аумақтарын дамыту мәселелері бірқатар қазақстандық ғалымдардың зерттеу нысаны болып табылады. Институционалдық қайта құрулардың жекелеген аспектілері, ауылдың әлеуметтікэкономикалық трансформациясы, ауыл шаруашылығын дамыту бағыттары Ш.У. Әкімбекованың [1], Ж.С. Бұлхайырованың [2], М.И. Сигаревтің, И.А. Палагинаның [3], С.В. Кулакованың [4], Б. Қалықованың [6] және т.б. еңбектерінде қаралды. сондай-ақ, КР Президенті Қасым-Жомарт Тоқаевтың Қазақстан халқына арнаған «Жаңа жағдайдағы Қазақстан: іс-қимыл кезеңі (2020 ж.)» және «Ауыл - ел бесігі» жобасының негізгі міндеттерін іске асыру мақсатында осы зерттеудің өзектілігі мен қажеттілігін анықтады.

Өз табиғаты бойынша кез-келген аумақ тірі, динамикалық шындықты білдіреді, оның сапасы мен даралығы табиғи жағдайлардың, инфрақұрылымның және экономикалық қызмет принциптерінің тікелей немесе жанама өлшенетін элементтерімен анықталады. Халық оған пішін, мазмұн береді, болашақты қамтамасыз етеді, өйткені адам қызметінің өндірістік күштерінің орналасуы аумақтық құрылымды анықтайды. Аумақтың өзіндік ерекшелігі оның экономикалық және әлеуметтік ерекшеліктерінде, демографиялық және мәдени аспектілерінде, экологиялық және саяси сипаттамаларында көрінеді. Аумақтың ұқсастығы мамандану процесінің нәтижесі болып табылатын экономиканың жетекші секторларын дамыту негізінде құрылады.

Аумақтың сапалық сипаттамалары жергілікті халықтың өмір сүру сапасын анықтайды. Олардың арасындағы симбиоз айқын, әсіресе ауылдық жерлерде. Ол ресурстық әлеуетке тәуелділікті анықтайды және ұзақ мерзімді аумақтық бәсекеге қабілеттілікті қамтамасыз етуде тиімді басқаруды талап етеді.
Ауылдық аумақтарды дамытуға алғаш рет Халықаралық еңбек ұйымы 1919 жылы құрылғаннан бастап баса назар аударды. Осы кезеңде ауыл шаруашылығын және ауылдық аумақтарды дамытуға тікелей бағытталған және еңбек саласындағы құқықтар, әлеуметтік қорғау, жұмысқа орналасу мүмкіндіктері, сондай-ақ әлеуметтік диалог сияқты тақырыптарға арналған 30-дан астам халықаралық еңбек нормалары қабылданды [6]. Дәстүрлі түрде өндірістік аспектіге бағдарланған ауылдық аумақтарды дамыту қолда бар әлеуеттен пайда алу, жергілікті өндірушінің рөлін күшейтуге бағытталған негізгі стратегиялық бағдарларға қатысты консенсус табу мүмкіндігіне үміт артуға тиіс. Бұл тәсіл экзогендік немесе өзгеруі қиын ауыспалы деп ауылдық жерлерді қабылдаудан эндогендік қабылдауға ауысуды білдіреді,, яғни табыс пен өмір сапасына көбірек әсер ету әдісіне ауысуды білдіреді.

Анықтамада біртектіліктің жоқтығына қарамастан, ауылдық жерлерді елдің әлеуметтік-экономикалық кеңістігінің негізгі элементтерінің бірі ретінде зерттеуге қатысты ортақ пікір бар, өйткені халықтың едәуір пайызы ауылдық жерлерде шоғырланған, бұл кең және әртүрлі табиғи және мәдени мұраның тірегі, жұмыспен қамту мен табыстың едәуір деңгейін қамтамасыз ететін көптеген экономикалық қызмет түрлерінің негізінде үлкен құндылық болып табылады.

\section{Әдебиетке шолу}

«Дамудың» көптеген анықтамалары бар, оны көбінесе үрдістер немесе өзгерістердің динамикалық бағыты ретінде түсіндіреді. Оксфорд сөздігінің анықтамасына сәйкес, жалпы «даму» дегеніміз «өзгермелі жағдайдағы жаңа кезенді білдіретін оқиға» немесе оң немесе қалаған күйге өзгерту үрлісін білдіреді [6]. «Үрдіс» даму үрдісіне айналуы үшін оны прогрессивті деп сипаттауға болатын бағыт қажет [7]. Егер біз қоғам немесе әлеуметтікэкономикалық жүйе туралы айтатын болсақ, «Даму», әдетте, жүйенің немесе оның жекелеген құрамдас элементтерінің жағдайын жақсартуды білдіреді [8]. Даму жақсартуға қол жеткізу үшін жеке өкілдермен немесе кезкелген органмен алдын-ала келісілген және қабылданған белгілі бір әрекеттер нәтижесінде пайда болады. П. Пирсонның пікірінше, «Даму» термині әлеуметтік-экономикалық қайта құру және қоршаған ортаны қазіргі сапалық және сандық күйден қолда бар ресурстарды пайдалану негізінде қалағанға дейін қалпына келтіру үшін қабылданған көптеген стратегиялар үшін гибридті болып табылады [9]. 
Анықтаманың кеңдігін ескере отырып, даму өзінің табиғаты бойынша көп өлшемді ұғым болып табылады, өйткені күрделі жүйелердегі, сондай-ақ нақты әлеуметтікэкономикалық жүйелердегі кез-келген жетілдіру әр түрлі жолмен, әр түрлі жылдамдықта жүруі және әртүрлі күштердің жетегінде жүруі мүмкін. Сонымен қатар, жүйенің бір бөлігінің дамуы қақтығыстарды тудыратын басқа бөліктердің дамуына белгілі бір зиян келтіруі мүмкін. Демек, дамуды өлшеу, яғни жүйенің шынымен және қаншалықты дамитынын анықтау өте күрделі және көп өлшемді әрекет болып табылады.

Аймақтың дамуы заманауи аймақтық экономика теориясының екі бағыты институционалдық экономикалық теория мен ресурстық тәсілдің синтезінің нәтижесі деп тұжырымдайтын Н.Ю.Сорокинаның пікірімен келіспеуге болмайды [10, б.. 22-23].

А.Сеннің анықтамасы бойынша аумақтардың дамуы экономикалық өмірге толыққанды қатысуды және әлеуметтік ұтқырлықты арттыруды қамтамасыз ететін автономия мен негізгі бостандықтарды нығайтуды білдіреді. Нәтижесінде адамдар экономика мен қоғамның дамуына қаншалықты көп қатысса, соғұрлым жаңа идеялардың пайда болуы мен таралуы, нақты кірістер мен өмір сүру сапасының көрсеткіштерінің өсуі үшін көп мүмкіндіктер пайда болады. А.Сеннің идеялары аумақтық дамуды инновация, транзакциялық шығындарды азайту және тауарлар мен қызметтерді өндіру мүмкіндіктерін пайдалану арқылы тиімділік пен өмір сапасының тұрақты өсуіне қол жеткізу құралы ретінде анықтауға ықпал етті [11].

Адамдардың негізгі қажеттіліктерін қанағаттандыру аумақтық дамудың маңызды элементі болып табылады. Негізгі қажеттіліктерге үй шаруашылықтарының жеке тамақтануының белгілі бір минимумы, тұрғын үй, тұруға қажетті тауарлар, сондай-ақ жалпы қоғам үшін ұсынылатын негізгі қызметтер (кауіпсіз ауыз су, санитария, қоғамдық көлік, Медициналық және білім беру қызметтері) кіреді.

Ауылдық аумақтарды дамыту тұжырымдамасы бүкіл әлемнің көптеген ғалымдарын қызықтырды [12]. Ауылдық орта, оны сипаттайтын элементтер (табиғи, экономикалық, мәдени және т.б.) туралы әртүрлі пікірлер бар. Бұл ауылдық аумақтарды дамыту туралы жалпы қабылданған түсініктің жоқтығын анықтайды. «Ауылдық жерлерді дамыту» термині әртүрлі түсіндірулерге ие болып қана қоймай, сонымен қатар соңғы онжылдықтарда тұжырымдама ретінде қарқынды дамып, мүлдем қарама-қарсы ұстанымдарды көрсетті. Стародубровская И.В. ауылдық аумақтардың экономикалық және әлеуметтік дамуын ажыратады. Экономикалық даму экономикалық қызметтің белгілі бір түрлерінің жұмыс істеуімен, жаңа қызмет түрлерінің пайда болуымен, әлеуметтік - адамдардың өмір сүру жағдайларының қалыптасуымен және адами капиталдың дамуымен байланысты [13]. Кейбір зерттеушілер үшін ауылдық жерлерді дамыту ауыл шаруашылығы мен ауыл өмірінің қолданыстағы моделіне қосымша болып табылады, ал басқа ғалымдар айтарлықтай қайта құруды талап етеді [14]. Ауылдық аймақтарды дамыту - бұл экономикалық мүдделер аясында кеңістікті біріктірудің нәтижесі болып табылатын жергілікті дамудың бір түрі деген пікір бар [15]. Сондықтан ол қызметтің барлық түрлері мен олардың өзара байланысын, мамандандырылған экономикалық және әлеуметтік құбылыстарды ескеретін жаһандық тәсілге негізделуі керек. Бірқатар авторлар ауылдарды дамыту аграрлық секторды дамытудың жаңа моделін білдіреді деп санайды [16].

Экономикалық қызметтің аумақтық орналасу теориясы екі параллель бағытта дамыды, оның интеграциясы тек жекелеген жағдайларда ғана қарастырылды. Жалпы бәсекелік тепе-теңдік моделінің негізін Д.Тюнен, А.Вебер, В.Кристалллер, А.Леш, В.Исард сияқты ғалымдар қалаған [17]. Бұл тәсіл 1960-1970 жылдары пайда болған аймақтық ғылым мектебіне айналды.

Екінші тәсілдің негізін қалаушы кластерлер теориясының, икемді индустрияландырудың, жаңа өнеркәсіптік аудандар мен инновациялық ортаның пайда болуы мен дамуына негіз болатын өнеркәсіптік агломерация процесі факторларының әсерін айқындаған А.Маршалл болып табылады. Кластердің белгілі бір кеңістікке әсерін зерттей келе, ол өндіріс шығындарының төмендеуінің белгілі бір локализацияланған сыртқы экономикалық факторлардың әсеріне тәуелділігін мыналармен түсіндірді:

- білікті жұмысшылар;

- мамандандырылған ресурстар мен қызметтерге қол жетімділік;

- өндірістік атмосфераның, қалыптасқан дәстүрлер мен құзыреттердің арқасында жаңа білімді тарату.

А.Маршаллдың тұжырымдарына сүйене отырып, П.Кругман дағдылар резервінің, сондай-ақ нарықтық байланыстар мен ақпарат пен білім ағындары арқылы құрылған мамандандырылған институттардың болуымен көрінетін масштабтағы центрифугалық күш- 
тердің, көлік шығындары мен сыртқы үнемдеудің маңыздылығын атап өтті. Р.Коуз, О.Уильямсон, С.Лаззарини және т.б. тік интеграция бойынша шығындарды азайту тетігі, агенттердің жеткізілім тізбегі бойынша күш-жігерін қосымша үйлестіру жөніндегі кейінгі әзірлемелері шарттық қатынастарды басқарумен байланысты аспектілерді зерттеуді тереңдетті [17]. М.Портер «кластерлер» және «бәсекеге қабілеттіліктің жүйелік сипаты» сияқты ұғымдарды енгізу арқылы бәсекелестік артықшылықтарды құру шарттарын зерттеуді кеңейтті. Тауарлар немесе қызметтер өндірісі үшін қажетті ресурстармен қамтамасыз етілу сипаты мен дәрежесін қамтитын Портер моделіндегі «салалардың географиялық кластерленуі» идеясына сәйкес жергілікті бәсекелестіктің түрі мен қарқындылығы; жергілікті өнімдерге сұраныс деңгейі; жергілікті жеткізушілер мен сабақтас салалардың саны мен сапасы аумақ экономикасы компоненттерінің маңыздылығы айқындалады [18].

Кластерлерді дамытудың шетелдік тәжірибесінің ішінде көп жағдайда жұмыс күші мен икемділікке жұмсалған шығындардан пайда алған, халықаралық бәсекеге қабілеттілікті қамтамасыз ететін диффузиялық индустрияландыруға алып келген ұсақ ауыл шаруашылығы өндірушілерін қамтитын итальяндық тәжірибе үлкен қызығушылық тудырады. Сарапшылар жергілікті дамудың барлық кезеңдеріндегі ұсақ ауылшаруашылық тауар өндірушілерінің стратегиялық рөлін атап өтеді, өйткені ол табиғи өндіріс пен тұрғын үйді ұсына отырып, халықтың эмиграциясын азайтуға көмектеседі, жергілікті жағдайларға бейімделген эндогендік бизнес бастамаларын адам ресурстарымен қамтамасыз етеді, арзан ресурстарға құндылық қосуға және әлемдік нарықтағы кең мүмкіндіктерді контекстік түсінуге ықпал етеді. Шағын шаруа қожалықтарын автономды басқару экономикалық бақылаудың кеңеюіне, жергілікті өндірісті қабылдауға, отбасылық шаруашылықтың мәдени дәстүрлерін өндірістік кәсіпорындарда жас отбасы мүшелерінің алған инновациялық білімімен үйлестіре отырып, мүмкін шығындарды азайтуға және отбасы табысын өсіруге болатын бизнес ретінде ықпал етті. Бұл процестің қозғаушы күші әртүрлі көлемдегі қалалық орталықтардың жергілікті автономды фермалармен, жалға алушы фермерлермен, ұсақ жер иелерімен өзара әрекеттесуі болды. Осылайша, аумақтың бәсекелестік әлеуеті, көбінесе, білім мен инновацияның таралуына ықпал ететін жергілікті институционалдық негіздің болуымен анықталады. Осы сипаттамаларды контексттеу үшін жеткізілім тізбегінің («кофехананың әсері») барлық қатысушылары арасында ұжымдық оқыту және бейресми білім алмасу арқылы жаңашылдыққа қабілетті «инновациялық орта» термині пайда болды. Нәтижесінде қатысушылардың арасындағы байланыстарды үйлестіруді тудыратын жер бедерінің табиғи қасиеттері бәсекелестік артықшылықты тудырады, бұл бір жағынан дамудың аумақтық аспектісін, ал екінші жағынан ұжымдық әрекетке ықпал ететін әлеуметтік ұйымды анықтайды.

Ғылыми әдебиеттерде ауыл типологиясының әртүрлі нұсқалары бар. Мысалы, ауылшаруашылық құрылымымен үйлескен динамикалық дамуға негізделген келесі типология бар:

- отбасылық фермерлік шаруашылықтар жақсы жұмыс істейтін және әлеуметтікэкономикалық орта икемді және әртараптандырылған аймақтық жағдай;

- аграрлық секторда да, аграрлық емес секторда да жұмысқа орналасуға мүмкіндік бере отырып, АӨК әлеуметтік-экономикалық ортамен үйлесетін өңірлік ахуал;

- агроөнеркәсіптік кешен мен фермерлік шаруашылықтар дағдарысты бастан кешіп жатқан аймақтық жағдай, ал әлеуметтікэкономикалық орта артық жұмыс күшін сіңіре алмайды;

- кең өндірістік жүйелер (көбінесе мал шаруашылығы) қатаң, мамандандырылған, еңбек үнемдейтін әлеуметтік-экономикалық ортамен үйлесетін депопуляция жағдайы;

- жерді қоныстандыру жақында ғана орын алған жағдай, ал әлеуметтік-экономикалық орта жеткілікті түрде тұрақты емес;

- экожүйе мен әлеуметтік-экономикалық ортаның осал болғаны соншалық, ауыл шаруашылығын жүргізу әдістерін қарқындату және аграрлық сектордан тыс жаңа жұмыс орындарын құру мүмкін емес [19].

Еуропалық ЛИДЕР бағдарламасы аумақтарды іс-әрекеттің дәйектілігі мен әлеуметтік интеграция дәрежесіне қарай жіктейді:

1-тип. Өндірісті трансформациялауда дамыған аумақтар іс-әрекеттерді ақылға қонымды деңгейде үйлестіруге және әлеуметтік интеграциялауға мүмкіндік беретін институционалдық даму деңгейіне жетті. Мұндай аумақтардың экономикасы серпінді нарықтармен бәсекелеседі. Сыртқы нарықтар тарапынан сұраныс, Мемлекеттік нормалар мен стандарттарға сәйкестік қажеттілігі, басқа өңірлер тарапынан бәсекелестік технологиялық инновацияларды ынталан- 
дырады. Қала мен ауыл арасындағы байланыстар техникалық, басқарушылық, еңбек мүмкіндіктерінің жоғары деңгейі, арзан ресурстардың, ақпараттық қызметтердің қолжетімділігі арқылы жоғары өнімділікті қамтамасыз етеді. Агенттер арасындағы тиімді қарым-қатынастар қабылданған ережелер, құқықтық шеңберлер, стандарттар арқылы сақталады және нақты әлеуметтік-инклюзивті сәйкестілікке ие. Аумақты сипаттайтын әлеуметтік-экономикалық қатынастар жекелеген фирмалар мен компаниялардың бәсекеге қабілеттілігін қамтамасыз етеді.

2-тип. Айтарлықтай экономикалық өсумен сипатталатын, бірақ жергілікті дамуға, атап айтқанда, ең кедей секторлар үшін айтарлықтай әсер етпейтін аумақтар. 1-типті аумақтар сияқты, олар да динамикалық нарықтармен байланысты күшті экономикалық секторларға ие. Алайда, біріншіден айырмашылығы, осы типтегі салалар институционалды түрде бөлінген және әдетте халықтың негізгі бөлігі арасында оқшауланудың кең таралуы нәтижесінде әлеуметтік қақтығысты көрсетеді. Қолданыстағы фирмалар аумаққа негізделген, бірақ оның дамуына оң әсер етпейді.

3-тип. Әсіресе күшті институционалдық құрылымдармен сипатталатын, көбінесе күшті мәдени ерекшелікте көрінетін, бірақ ауылдағы кедейліктің жойылуын қолдаудың экономикалық баламалары жоқ аймақтар.

4 түрі. Қоғамдық қайта құру процесімен қамтылған аумақтар. 3 типке ұқсас, олар депрессиялық және тоқырау экономикасымен сипатталады. Бірақ олар жергілікті деңгейде жағымды өмірді құруға іс жүзінде мүмкіндік беретін институттардың жоқтығымен ерекшеленеді [20].

Дәстүрлі түрде ауылдық жерлер өздерінің құндылықтарынан немесе атрибуттарынан гөрі қалалық ортасынан өзгешеліктерімен сипатталатын орындар ретінде қабылданды. Олар көбінесе инфрақұрылым мен жабдықтардың жетіспеушілігі жиі байқалатын, халықтың әлеуметтік-экономикалық алға жылжуына мүмкіндіктері жоқ жерлер ретінде анықталады. Ауылдық жерлердің проблемасы - бұл негізгі нарықтардан экономикалық қашықтық, бәсекеге қабілеттілікті төмендетін экономикалық қызметтің шашыраңқы және ұсақ сипаты.

Сонымен қатар, құрылымдық факторларды, жаһандануға, ғылыми-техникалық дамуға байланысты жүріп жатқан процестерді, ойынның экономикалық ережелерінің өзгеруін және т.б. ескеру қажет.

Экономиканың заманауи ашықтығы проблемалардың үш түрін анықтайтын әлемдік нарықтардағы бәсекеге қабілеттілік деңгейіне тәуелділіктің артуына алып келеді:

- жағдайды бақылаудың шектеулі мүмкіндігін ескере отырып, дамушы экономикалардың әлемдік күйзелістер алдындағы үлкен макроэкономикалық осалдығы;

- ауылдық жерлерде қол еңбегінің төмен маневрлік қабілеттілігі мен капиталдың мобильділігінің артуы арасындағы тепе-т еңдік;

- дамыған елдердегі жаңа технологиялардың шоғырлануы.

Тағы бір анықтаушы фактор - агро азық-түлік өнеркәсібін шоғырландыру және трансұлттықтандыру тенденциясы, тұрақты шетелдік инвестицияларды тарту саясатының нәтижесінде жеделдетілген үдеріс. Нәтижесінде, көптеген елдердегі азық-түліктің бөлшек сауда нарықтарында бөлшек сауда орындары басым болып, ауыл тауар өндірушілері үшін айтарлықтай қиындықтар туғызды.

Әлеуметтік-экономикалық жүйелерді дамыту үшін қабылданған өткен және қазіргі «парадигмалардың» толық жиынтығын нықтау әртүрлі факторлардың әсерінен, яғни даму тұжырымдамасының күрделілігі және оның көп өлшемділігі, даму саясаты мен қол жеткізілген нәтижелер арасындағы себепсалдарлық байланыстарды анықтаудағы аналитикалық қиындықтар, сондай-ақ көптеген басқа себептерді өлшеу және бақылау қиындықтары салдарынан туындайтын өте күрделі міндет. Алайда, өткен процестер мен болып жатқан өзгерістерді бағалау жаңа перспективалар үшін маңызды.

\section{Әдіснама}

Зерттеудің әдіснамалық және теориялық негізі ауыл дамуын, аграрлық экономиканы, ауыл халқының әлеуметтік-экономикалық проблемаларын, экономикалық дамудың шетелдік бағдарламаларын зерттеу саласындағы шетелдік ғалымдардың еңбектері болды, олардың синтезі ауылдық аумақтарды дамытудың авторлық тұжырымдамалық моделін қалыптастыруға мүмкіндік берді. Ғылыми абстракцияның, талдау мен синтездің жалпы ғылыми әдістерін, жүйелі тәсілді пайдалану ауылдың даму проблемасын кешенді және жүйелі зерттеуге мүмкіндік берді. Зерттеу сонымен қатар зерттелетін объектінің мәнін сипаттайтын негізгі белгілерді анықтауға, сондай-ақ қолданылатын әдістер мен механизмдер арасындағы қасиеттер мен қатынастарда ұқсастықты анықтауға мүмкіндік беретін абстрактілі-логикалық, монографиялық, жүйелік-құрылымдық зерттеу әдістерін қолдана отырып жүргізілді. 
Абстрактілі-логикалық әдісті қолдану зерттеу гипотезасын тексеруге және растауға мүмкіндік берді, ол мыналардан тұрды: ауылдық аумақтардың дамуы ауылшаруашылық өндірісінің даму динамикасына, экономика құрылымын әртараптандыруға, инфрақұрылымды дамытуға және институционалдық дамуға байланысты. Ауыл жағдайында өндірісті, кооперацияны ұйымдастырудың алдыңғы қатарлы шетелдік тәжірибесіне шолу жасау кезінде монографиялық әдіс қолданылды. Ауылдың экономикалық жүйесінің қолданыстағы өзара байланыстары негізінде жүйелік-құрылымдық тәсіл қолданылатын тетіктердің нәтижелілігін анықтауға мүмкіндік берді. Алынған қорытындылардың көрнекілігін қамтамасыз ету үшін ауылдық аумақтарды дамытудың тұжырымдамалық моделінің авторлық пайымын графикалық түрде ұсынуға мүмкіндік беретін визуализация әдісі пайдаланылды.

Жүргізілген талдау шетелдік, ресейлік және отандық ғалымдардың «даму», «ауылдық аумақтар», «ауылдық аумақтарды дамыту» ұғымдарын анықтау тәсілдерін жүйелеу негізінде негізделеді.

\section{Нәтижелер мен пікірталас}

Аумақтарды дамытуды кедейлікті жою, жұмыспен қамтуды қамтамасыз ету, теңсіздікті азайту және адам құқықтарын қамтамасыз ету сияқты күрделі мақсаттарға қол жеткізудегі прогресс ретінде қарау керек, бұл дамудың қозғаушы күші болуға ғана емес, сонымен бірге белгілі бір артықшылықтарға ие болуға мүмкіндік береді [21]. Аумақтық даму, әдетте, жергілікті экономиканың тиісті өсу процесі арқылы жергілікті халықтың өмір сүру деңгейін арттыруға, кірістердің өсуіне, тұтынылатын қызметтерді (әсіресе медициналық және білім беру) жақсартуға бағытталған. Әлеуметтік, саяси және экономикалық жүйелер мен институттарды құру адамның қадір-қасиеті мен құрметінің дамуына ықпал етеді, адамдардың таңдау еркіндігін арттырады [22].

Аумақтық дамуға нақты кеңістіктің өзіндік әлеуметтік-экономикалық, экологиялық және институционалдық әлеуетін пайдалану және сыртқы субъектілермен өзара қарымқатынастарды құру нәтижесінде қол жеткізуге болады. Бұл кеңістіктегі белгілі бір қатынастар жиынтығы ретінде құрылған, адамның ісәрекеті үшін тартылыс полюстерінің болуымен сипатталатын (тауарлар мен қызметтерді өндіру және тұтыну, сонымен қатар мәдениет және әлеуметтік өмір) және ақпараттық жүйелер мен көлік инфрақұрылымымен байланысты аумақтық жүйеге жатады [8].
Аумақтық даму аумақтың активтеріне, оның әлеуеті мен шектеулеріне назар аударуды қамтиды [23]. Даму процесінде оң өзгерістерді ілгерілету үшін қажетті осы әлеуетті пайдалану және арттыру саясаты маңызды рөл атқарады. Аумақтық кеңістік кәсіпкерлікті дамыту және инновацияларды енгізу мүмкіндіктерін қалыптастыру үшін маңызды фактор болып табылады [11].

Әртүрлі кезеңдерде халықаралық қоғамдастық дамуға қол жеткізудің белгілі бір тәсілдерін бөліп көрсетті, оларды кодталған іс-қимыл жиынтығы негізінде және / немесе әлеуметтік-экономикалық жүйенің жұмыс істеуі мен эволюциясына қатысты пайымдау негізінде мақсатқа қол жеткізу үшін ұстану керек.

Ғылыми әдебиеттерде ауылдық аумақтардың дамуы даулы ұғым екенін кеңінен мойындайды. Сонымен қатар, ауылдық жерлерді қалалықтан ажыратуға мүмкіндік беретін әртүрлі критерийлерді қолданумен байланысты анықтаманың өзі бір елде өзгеруі мүмкін. Алайда, көптеген елдерде, әдетте, «ауыл» деп аталатын аудандарда оларды ажыратуға мүмкіндік беретін бірнеше ортақ белгілер бар: кәсібі, популяциясы, тығыздығы, еңбек нарығы немесе елді мекен контексті және т.б.

Зерттеу тақырыбы бойынша ғылыми тұжырымдамаларға теориялық шолу ауылдық аумақтарды дамытудың өзіндік анықтамасын қалыптастыруға мүмкіндік берді - жергілікті ресурстық әлеует пен бәсекелестік артықшылықтарды пайдалануға негізделген әлеуметтік-экономикалық сипаттағы проблемаларды жақсартуға және халықтың өмір сүру деңгейін арттыруға бағытталған үрдіс.

Ауылдық аумақтарды дамыту - бұл ауыл шаруашылығын дамыту және ел экономикасының үдемелі қозғалысы моделіне негізделген күрделі үрдіс. Ауылдық аумақтарды дамыту үрдісінің негізгі мазмұны осы мақаланың авторлары ұсынған ауылдық аудандарды дамыту саясатының эволюциясын талдау және осы аумақтардың дамуын тұжырымдамалау негізінде құрылған модельді көрсетеді (1-сурет).

Аумақтың жергілікті әлеуеті қол жетімділікке және өзара әрекеттесуге байланысты:

- табиғи ресурстар;

- жұмсақ және қатты инфрақұрылым;

- институционалдық активтер (жергілікті әлеуметтік-мәдени нормалар);

- жергілікті халықтың ноу-хау мен құзыреті. 

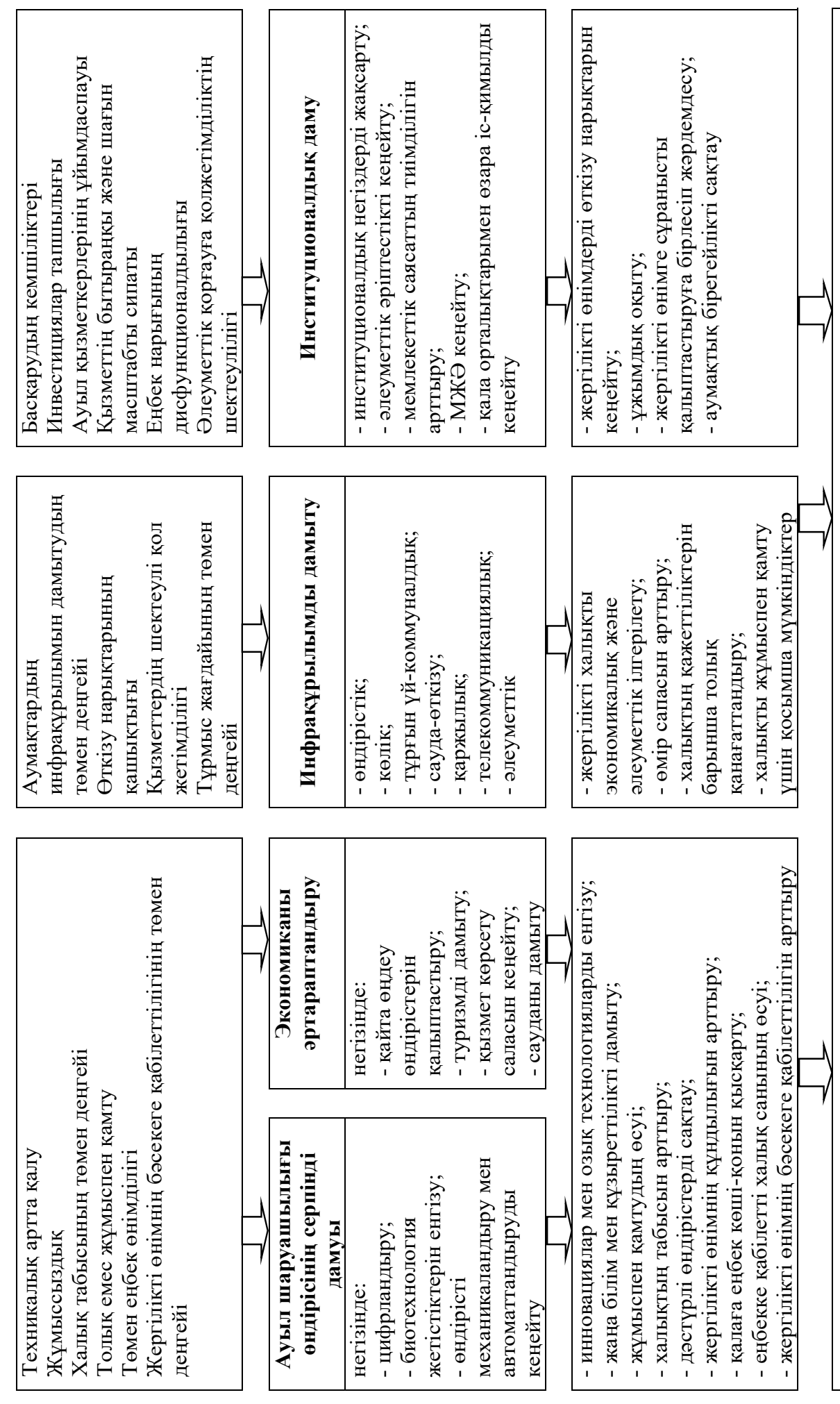

党
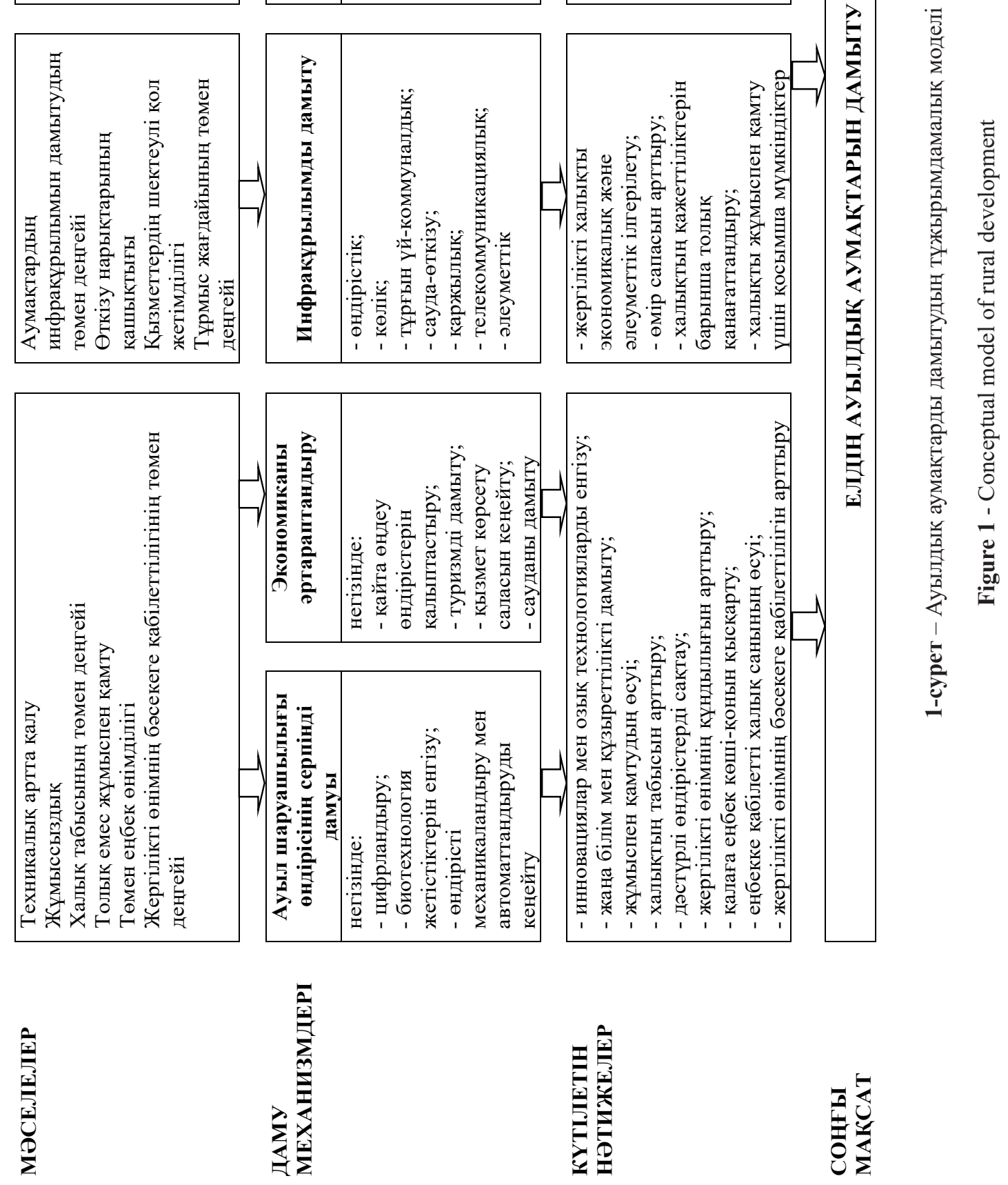
Осылайша, жергілікті экономикалық дамудың негізгі принциптері бірқатар элементтерді біріктіру арқылы құрылады. Техникалық прогресс пен білім деңгейі жергілікті өндірістің бәсекеге қабілеттілігін қамтамасыз етеді, жұмыспен қамтуға, табыстың өсуіне, ауыл халқының өмір сүру деңгейінің артуына кепілдік береді. Технологиялық инновациялар еңбек өнімділігін арттыруға ықпал етеді, қолда бар ресурстарды жоғары сұранысқа ие, тиісінше қымбатырақ, жоғары сұранысқа ие қайта өңделген өнімдерге айналдыруға мүмкіндік береді. Өнімділік пен кірістілікті арттырудың негізгі факторы басқа өңірлер тарапынан жергілікті өнімге сұраныс болып табылады, сондықтан жергілікті өндірушілердің өндірістік куатын арттыру маңызды. Ресурстар мен ноу-хауға қол жеткізу арқылы кәсіпорындардың (ауыл шаруашылығы және ауыл шаруашылығы емес) өміршендігін айқындайтын қала мен ауыл арасындағы байланыс сыртқы сұраныстың әрекет ету арнасына айналады. Институционалды даму, әсіресе өзара әлеуметтік қатынастардың сенімді желілерінің, аумақтық сәйкестіліктің болуына қатысты, ұжымдық оқытуға, техникалық білімнің таралуына, прогреске және бәсекеге қабілеттілікке ықпал етеді. Аумақты құру тек объективті физикалық кеңістік ретінде ғана емес, сонымен бірге жеке басын куәландыратын әлеуметтік қатынастардың жиынтығы ретінде мүдделер мен тілектердің сәйкес келуіне негізделген даму жобасына мән мен мазмұн береді.

Ауылдық аумақтарда «өсу қозғалтқышының» рөлін ауыл шаруашылығы атқаратыны сөзсіз, елді азық-түлікпен қамтамасыз ету, өнеркәсіптік өндірісті шикізатпен қамтамасыз ету, жергілікті халыққа жұмыс орындары мен табыс көздерін ұсыну мәселесі шешуші рөл атқарады, сондықтан динамикалық ауыл шаруашылығы секторы ауылдық аудандарды дамытудың ең бастысы болуға тиіс. Бірақ ғылымитехникалық прогрестің жетістіктерін енгізусіз даму мүмкін емес. Адамдар 10.000 жылдан астам уақыт бойы егіншілікпен айналысқан, бірақ соңғы 60 жыл ішінде (немесе одан да көп) ауыл шаруашылығы айтарлықтай өзгерістерге ұшырады. Механикаландырылған ауылшаруашылық техникасы, синтетикалық агрохимикаттарды қолдануға негізделген заманауи революциялық технологиялар дақылдардың өнімділігін едәуір арттырды. Қазіргі уақытта ауылшаруашылық әдістерінде жасанды интеллект, тиісті автоматтандыру және инновациялық бақылау құрылғылары келесі міндеттерді орындауды жақсартуға арналған: егу, өсуді басқару, суды тұтыну, энергияны үнемдеу, егу және жинау, өсімдіктерді орау және дайындау сияқты цифрлық технологияларды қолдану негізінде нақты егіншілікке көшу басталады. Өсімдік геномикасы саласындағы жетістіктер өнімділікті арттыруға, өнімнің дәмін жақсартуға және қосымша қоректік заттармен өсімдіктерді өсіруге бағытталған [24].

Ауылда өмір сүру сапасын арттыру үшін ауыл шаруашылығынан ауыл шаруашылығына жатпайтын секторларға: қайта өңдеу, коммуналдық қызметтер, құрылыс, сауда, туризм, көлік, қаржы, мемлекеттік және т.б. қызметке көшуді көздейтін ауыл экономикасын әртараптандыру елеулі әлеуетке ие. Мұндай трансформацияны қамтамасыз ететін қозғалтқыш ауыл шаруашылығының өсуі және оның өнімділігінің артуы болып табылады, бұл басқа салаларды ынталандыру үшін айтарлықтай мультипликативті әсер береді.

Ауыл шаруашылығына жатпайтын бағыт барған сайын қолайлы нұсқаға айналады, өйткені ол, әдетте, серпінді аудандарда кірістіліктің үлкен әлеуетіне ие. Микро және шағын кәсіпкерлер стандартты емес қызмет түрлерін жүзеге асыруда көп жағдайда жергілікті өндіріс пен аумақтан тыс нарықтар арасында сұраныстың күшті динамикасымен қатынастардың пайда болуына байланысты табысқа жетеді, бұл бір жағынан, қалыптасып жатқан әлеуметтікэкономикалық қатынастарды құрылымдау, екінші жағынан жаңа экономикалық мүмкіндіктерге кедей секторларды тартуға ықпал ететін жаңа институционалдық тетіктерді талап етеді. Экономиканы әртараптандыру табыс деңгейінің төмендеуі және ауыл халқының еңбек көші-қонының өсуі жағдайында оң нәтиже береді.

Бұл жағдайда артықшылықтар келесілер есебінен қамтамасыз етіледі:

табиғи ресурстардың болуы: ауыл шаруашылығы өнімдері, туристікрекреациялық;

- ауылшаруашылық өнімдерін/табиғи ресурстарды өндіріс пен өндіріске жақын жерде өңдеу, бұл көлік шығындарын қысқартады және қалдықтарды азайтады;

- ауыл шаруашылығын жүргізуде бірегей білікті еңбектің, дәстүрлі қолөнердің болуы;

- арзан жұмыс күшінің болуы (әсіресе маусымнан тыс уақытта) [25].

Ауыл шаруашылығы секторы ауылдық жерлерде экономиканы әртараптандырудың және секторлар арасындағы орнықты байланыстың маңызды құрауышы, сондай-ақ құрылымдық қайта құрулар драйвері болып 
танылады. Мұндай байланыс жанама түрде кірістер немесе инвестициялар арқылы өндірістік қызметпен іске асырылады. Өндірістік байланыстар ауыл шаруашылығы өнімдерін қайта өндеуді және бөлуді қосымша кеңейтуді талап ететін, көрсетілетін қызметтер секторының ұлғаюына себепші болатын ауыл шаруашылығы секторының өсуі нәтижесінде туындайды. Экономикалық әртараптандыру процесі ауылшаруашылық емес секторларға сұраныс пен ұсыныс тудыратын ауылшаруашылық секторының өнімділігіне байланысты.

Көптеген елдердің ауылдық жерлеріндегі жұмыспен қамту модельдері көптеген үй шаруашылықтары фермерлік және фермерлік емес көздерден ақша табуға тырысатындығын көрсетеді [5]. Нәтижесінде, үй шаруашылықтарының ауылшаруашылық емес экономикаға қатысуы толық емес жұмыс түрін қабылдауы немесе маусымдық сипатқа ие болуы мүмкін, өйткені экономикалық әртараптандыру қосымша жұмыспен қамтуды, кірісті арттыруды қамтамасыз ете алады.

Бұдан басқа, өндіріс орындарында ауыл шаруашылығы өнімін қайта өңдеу құнды қосу нәтижесінде қосымша пайда алуға мүмкіндік береді, жергілікті халықтың құзыреті мен білімін кеңейтеді, кооперативтер мен басқа да кәсіпорындарды құру арқылы әлеуметтік және ынтымақты экономиканың дамуын қамтамасыз етеді. Инклюзивті әлеуметтікэкономикалық дамудың және ауылдық жерлерде кедейлікті азайтудың катализаторы туризм (экологиялық, ауылдық) болуы мүмкін.

Инклюзивті ауыл шаруашылығының өсуін қолдау ауылдық аумақтарда өмір сүру жағдайларын жақсартуды қамтамасыз етеді. Ауыл экономикасындағы сапалы қызметтерге қол жеткізуді қамтамасыз ету әлеуметтік дамуға жәрдемдеседі.

«Ауылдық аумақтарды дамыту» парадигмасы тек ауыл шаруашылығын дамытуға ғана емес, сонымен бірге бір ауылдық жерде тұратын агенттер арасындағы экономикалық қатынастарды, ауылдық кеңістіктің басқа кеңістіктермен (қалалық, қала маңындағы немесе басқа ауылдық) қатынастарын дамытуға баса назар аударады.

Дамудың маңызды факторы - сапалы институттардың, яғни ойын ережелері, мәжбүрлеу тетіктері немесе белгілі бір ережелер мен рәсімдерге сәйкес әрекет ететін, транзакциялық шығындарды төмендететін және ықтимал нәтижелер ауқымымен сенімділікті арттыратын қоғамда қабылданған мінез-құлық стандарттарының болуы [17].
Даму бағдарламалары кешенді институционалдық архитектураны қажет етеді, оны ұйымдар мен мекемелер бір мақсатқа жету үшін қалыптастырылатын реттелетін құрылым деп түсінеді: министрліктер, фирмалар, ҮЕҰ, кооперативтер, институттар және т.б. Ынтымақтастықты ынталандырудағы шешуші рөлді дәстүрлі әкімшілік тетіктерді қолдану арқылы секторлар бойынша әрекет ететін мемлекеттік органдар атқарады: ауыл шаруашылығы, қоршаған ортаны қорғау, денсаулық сақтау, білім, әлеуметтік қамсыздандыру министрліктері, сондай-ақ әлеуметтік қорлар, ауылшаруашылық мекемелері сияқты әртүрлі автономды ведомстволар.

Барлық деңгейлердегі басқарудың икемді контексті шеңберінде барлық секторларды қарайтын мемлекеттік саясат ауылдық аудандарды дамыту проблемасын шешудің неғұрлым толық және жан-жақты тәсілі болып қала береді. Мұндай саясат аумақтардың тұрақты дамуы үшін эндогендік және экзогендік ресурстарды пайдалану мақсатында халықтың екі тобы арасындағы қажетті синергияға ықпал ете отырып, ауылдық және қалалық орта арасындағы ынтымақтастық стратегиясын ынталандыруы тиіс.

Ауылдық жерлердегі жеке ұйымдар саясатқа және іс-қимыл формаларына әсер ету қабілетінде айтарлықтай ерекшеленеді. Сөзсіз көшбасшылар - бұл кәсіпорындарды олардың салалық юрисдикциясынан тыс динамикалық қызметпен біріктіретін ұйымдар. Мұндай ұйымдар даму бағдарламаларының функционалды келісімдерін қалыптастыруда маңызды рөл атқарады.

Күшті институционалдық архитектура келесі элементтердің болуымен және сапасымен байланысты:

- жергілікті үкіметтің техникалық, әкімшілік, саяси сипаттамалары мен мүмкіндіктерін;

- биліктің әртүрлі деңгейлері арасындағы іс-қимылдарды үйлестіру (ұлттық, өңірлік, жергілікті);

- өндірістік трансформация міндеттерін орындауға қабілетті желілер мен бірлестіктердің басқа да типтері;

- экономикалық міндеттер мен азаматтық қоғам мәселелерін шешу;

- аумақты дамыту үшін өзекті масштабтар мен облыстардағы мемлекеттік және жеке меншік секторлардың іс-қимылдарын келісу форумдары мен тетіктерін айқындайды.

Даму бағдарламалары орта мерзімді және ұзақ мерзімді перспективада тұжырымдалуы және басқарылуы тиіс. Әртүрлі агенттер уақыт шеңберлерінің дұрыстығы 
туралы әртүрлі түсінікке ие, сондықтан мұндай келіспеушіліктерді жоюдың кілті аумақты дамыту әлеуеті мен осыған байланысты жағдайлардың жалпы көрінісін қалыптастыру болып табылады, бұл тікелей қажеттіліктерді қанағаттандыруды бірлескен іс-қимыл процесінің қадамдарына айналдыруға мүмкіндік береді.

Балама тәсілдерді зерттеу және табысқа жетудің үлкен мүмкіндігіне кепілдік беретін ауылдық даму стратегиясын таңдау мәселесі өте маңызды. Ал оның нәтижесі қазіргі алғышарттарды алдын-ала бағалауға және мемлекеттік бағдарламаларды іске асырудың тиімділігін талдауға байланысты болады.

Ауылдық даму саясатының эволюциясы ауылдық жерлердегі қоршаған ортадағы ейбір қарқынды өзгерістердің және сәйкесінше осы аумақтардың дамуын тұжырымдамалаудың салдары болды. Ауыл мен қала ортасының арасындағы айырмашылықты азайту олардың өмір сүру деңгейін теңестіруге және халықтың тиісті топтары арасындағы әлеуметтік-экономикалық өзара әрекеттесуді күшейтуге ықпал етеді. Ауылдық және қалалық аймақтарды синтездеудің қызықты және жаңартылған процесі аясында аумақтардың жаңа сипаттамалары бола алатын экономикалық және әлеуметтік динамика пайда болады.

Аумақтық даму жөніндегі жұмыстың өмірлік маңызды құрамдас бөлігі адамдар болып табылатындықтан, күрделі экономикалық, әлеуметтік, саяси, экологиялық, мәдени және демографиялық өзара байланыстарды талдаудың барлық құралдарына ие, қалаған және мүмкін болатын тепе-теңдікті табу, баламаларды белгілеуге және басымдықтарды таңдауға қабілетті ауылдық аудандарды дамытуға оқытылған жас мамандарды тарту үшін барлық қажетті жағдайларды жасау қажет.

Ауылдық аумақтарды дамытуды кедейлік пен теңсіздікті азайтуға бағытталған бір мезгілде өндірістік трансформация және институционалдық өзгерістер процесі ретінде қарастыруға болады. Өндірістік трансформация өңірдің экономикасы серпінді дамуы және ауылдық жерлердегі дәстүрлі жұмыспен қамтудағы өзгерістерді болжайтын өзіне тұрақты бәсекеге қабілеттілікті қамтамасыз етуі үшін қажет. Институционалдық даму жергілікті мүдделі тараптардың өзара әрі сыртқы агенттермен келісілген іс-қимылдарына жәрдемдесуге бағытталған, формальды және бейресми ережелерді өзгертуге бағытталған.

Өндірістік трансформация мен институционалдық даму бір мезгілде ҒЗТКЖ бағдарламаларымен қамтамасыз етілуге тиіс.
Бәсекелестіктің жүйелі сипатын және технологиялық инновацияларға үнемі қажеттілікті, серпінді нарықтардың қол жетімділігін қамтамасыз ету үшін қала мен ауыл арасындағы байланыс қажеттілігін ескере отырып, тиісті серіктестіксіз, ноу-хау мен дағдылармен алмасусыз өндірістік тізбектегі ортақ мақсаттарға қол жеткізу мүмкін емес.

Әрбір даму процесіндегі аумақ физикалық және экономикалық айнымалылар жиынтығымен анықталатын объективті түрде бар кеңістік қана емес, сонымен бірге белгілі бір мүдделі тараптар, даму мақсаттары мен міндеттері бар әлеуметтік құрылым болып табылады. Бұл ретте, ауданның тұрмыс деңгейін жақсартудың негізгі элементтері жергілікті жердің мәдени ерекшеліктері, дәстүрлі қолөнер, аумақтық дамудың тарихи қалыптасқан ерекшеліктері қарастырылады.

Ауылды дамыту бағдарламалары ауыл кәсіпорындары мен супермаркеттер, мейрамхана желілері арасында жеткізу шарттарын жасасу, өндірушілер қауымдастықтарының ауқымын үнемдеуге қол жеткізу, инфрақұрылымдық және сервистік мәселелерді еңсеру, микрокредиттеудің транзакциялық шығындарын жабу үшін субсидиялар мен кепілдіктер беру мәселелерін бірлесіп шешу үшін әртүрлі мүдделі тараптарды тартуы тиіс.

\section{Қорытынды}

Осылайша, ауылдық елді мекендердің даму ерекшелігі негізінен ауылшаруашылық өндірісінің дағдарыстық құбылыстарымен, өмір сүру сапасының төмен деңгейімен, жұмыссыздықтың өсуімен және еңбекке қабілетті халықтың кетуімен сипатталады. Ауылдық аумақтардың қазіргі мәселелері замануи әлеуметтік-экономикалық жағдайларға бейімделуге мүмкіндік беретін олардың құрылымдық және функционалдық түрленуін болжайтын дамудың жаңа тәсілдерін, тетіктері мен бағыттарын әзірлеу қажеттілігін негіздейді. Ауылдық қоғамдастықтың мүмкіндіктері мен әл-ауқатын жақсарту процесі ретінде ауылдық аудандарды дамытудың жоғарыда келтірілген анықтамасы жергілікті халықтың өмір сүру жағдайы мен сапасын жақсартуға бағытталған мақсаттарға қол жеткізу үшін біріктірілетін әртүрлі элементтер мен процестерді ажыратуға мүмкіндік береді.

Ауылдық аумақтарды дамыту аумақтық жоспарлау, халықтың табыс деңгейін арттыру, жерге иелік ету және өндіріс құрылымы, салалық және аумақтық мүдделер қақтығысы, мүдделі тараптардың өзара қарым-қатынасы 
мәселелерінің түйінді шешімдерімен байланысты екені анық.

Аумақтық тұтастық, әлеуметтік әріптестік, институционалдық ынтымақтастық, экологиялық орнықтылық және басқару ауылдық ортаның үздіксіз дамуын қамтамасыз ететін саясаттың іргелі элементтері болып табылады. Ауылдық аумақтарды дамытудың факторлары: қала мен ауыл арасындағы күшті өзара іс-қимыл; жол коммуникацияларын кеңінен дамыту; жаңа ақпараттық технологиялар (АТ) мен білімнің жаппай таралуы; ел халқының ауылдық жердің маңызын жаңа түсінуі; көші-қон ағындарының сипатын өзгерту болуы мүмкін; табиғи кеңістіктерге қойылатын жаңа әлеуметтік талаптар; тұтынушылардың тамақ өнімдерінің денсаулығы мен қауіпсіздігіне қатысты талаптарының өсуі; экологиялық және ландшафтық аспектілердің екіұштылығын жою, ауылдық жерлерде сатылатын Экономикалық қызмет түрлерінің өсіп келе жатқан саны, таза энергияны пайдалану және аумақтық жоспарлау қажеттілігі.

\section{Пайдаланылван әдебиеттер тізімі}

1. Акимбекова, Ч.У. (2021). Проблемы и перспективы казахстанского села в условиях развития сельских территорий. Официальный сайт казахстанской сельскохозяйственной газеты «Аграрий Казахстана», 7(117), 6-7. http://abkaz. kz/problemy-i-perspektivy-kazaxstanskogo-sela-vusloviyax-razvitiya-selskix-territorij/. Дата обращения 23.07.2021.

2. Булхаирова, Ж.С. (2013). Устойчивое развитие сельских территорий Казахстана. Lap Lambert Academic Publishing, 272. Дата обращения 10.05.21.

3. Сигарев, М.И., Палагина, И.А. (2013). Формирование механизма устойчивого развития сельских территорий Казахстана. ҚазЭУ хабаршысысы, 3, 15-20.

4. Кулакова, С.В. (2021). Аспекты устойчивого развития сельских территорий Республики Казахстан. Чебоксары: ИД «Среда». Экономика и право, 22-37.

5. Kalykova, B. (2020). Rural Territories of Kazakhstan: Realities, Problems and Solutions. Problems of AgriMarket, 3, 209-215. https://doi. org/10.46666/2020.2708-9991.26

6. An official website of the International Labour Organization (ILO). Economic Diversification of the Rural Economy. https://www.ilo.org/global/topics/ economic-and-social-development/rural-development/ WCMS 437176/lang--en/index.htm. Дата обращения 27.01 .2021

7.Oxford English Dictionary. http:// oxforddictionaries.com Oxford English Dictionary. http://oxforddictionaries.com. Дата обращения 23.12.2020

8. Бык, Ф.Л., Китушин, В.Г. (2008). Концептуальная модель управления развитием. Менеджмент в России и за рубежсм, 6, 12-19.

9. Bellù, L.G..Development and Development Paradigms A (Reasoned) Review of Prevailing Visions. Food and Agriculture Organization of the United Nations, Rome. http://www.fao.org/docs/up/ easypol/882/defining development paradigms 102en. pdf. Дата_обращения 13.01.2021.

10. Pearson, P. D., Roehler, L.R., Dole, J.A., Duffy, G.G. (1992). Developing expertise in reading comprehension. In S.J. Samuels \& A.E. Farstrup (Eds.), What Research Has to Say About Reading Instruction (2nd ed., pp. 145-199). Newark, DE: International Reading Association.

ht t p s: // w w w.researchgate.net/ publication/313196587 Developing expertise in reading_comprehension. Дата обращения 11.01.2021.

11. Сорокина, Н. Ю. (2013). Концептуальная модель устойчивого развития региона. Регион, 3-4, 22-27.

12. Feldman, M., Hadjimichael, T., Lanahan, L., Kemeny, T. (2016). The logic of economic development: a definition and model for investment. Environment and Planning C: Government and Policy. 34, 5-21. doi: 10.1177/0263774X15614653

13. Molina, J.P. (2010). Keys for rural territorial development. Agron. Colomb., 28(3). https:// revistas.unal.edu.co/index.php/agrocol/article/ view/15313/28810. Дата обращения 18.01.2021

14. Стародубровская, И. В., Миронова Н. И. (2010). Проблемь сельского развития в условиях муниципальной реформы в России. М.:Институт экономической политики имени Е.Т. Гайдара, 116.

https:// w w w.i e p.ru/files/Re P E c/ga i/ rpaper/69Starodubrovskaya.pdf. Дата обращения 11.12.2020

15. De Janvry, A., Sadoulet, E. (2007). Toward a territorial approach to rural development. Journal of Agricultural and Development Economics, 4(1), 66-98. http://www.fao.org/3/a-ai192e.pdf. Дата обращения 14.01.2021

16. Gallardo-Cobos, R..(2010). Rural development in the European Union: the concept and the policy. Bogotá:Agron. Colomb, 28(3). http://www.scielo.org. co/scielo.php?script=sci. Дата обращения 09.01.2021

17. van der Ploeg, J. D., Renting, H., Brunori, G., Knickel, K., Mannion, J., \& Marsden, T. (2000). Rural Development: From Practices and Policies towards Theory// Sociologia Ruralis. - 2000. - № 40(4). - P. 391-408. https://doi.org/10.1111/1467-9523.00156.

18. Schejtman, A., Berdegué, J.A. (2004). Rural Territorial Development, 67.

https://www.rimisp.org/wp-content/files mf/13663830272004 schejtman berdegue rural territorial development.pdf. Дата обращения 11.02.21

19. Porter, M.E. (1998). Clusters and the new economics of competition. Harvard Business Review, November-December, 77-90. http://backonline.apswiss. $\mathrm{ch} / 6001 /$ porter clusters and the new economics of competition.pdf. Дата обращения 08.02.2021 
20. Hodge, I; Midmore, P. (2008). Models of Rural Development and Approaches To Analysis Evaluation And Decision-Making. Économie rurale Agricultures, alimentations, territoires,307. http:// journals.openedition.org/economierurale/406. Дата обращения 11.01.2021

21. An official website of the European Union. Rural development programmes per country. ec.europa. eu/info/food-farming-fisheries/key-policies/commonagricultural-policy/rural-development/country. Дата обращения 27.12.2020.

22. Abuiyada, R. (2018). Traditional Development Theories have failed to Address the Needs of the majority of People at Grassroots Levels with Reference to GAD. International Journal of Business and Social Science, 9(9). doi:10.30845/ijbss.v9n9p12.

23. Abyu, G. Y. (2020). Concept of Development. Bahir Dar University, doi: 10.13140/ RG.2.2.24951.16800 Available from:

https://www.researchgate.net/publication/340127781 Concept of Development/. Дата обращения 20.02.2021.

24. Francois, J., Josling, T., Raney, T., Stringer, R., Deuss, A., Skoet, J., Martin, W. (2005). The State of Food and Agriculture. Agricultural trade and poverty Can trade work for the poor? Rome: Chief Publishing Management Service Information Division. - 2005. - fao.org/3/a0050e/a0050e00.htm. Дата обращения 01.03.2021.

25. Rosen, L. (2018). Agriculture Working with New Technologies to Increase Food Security in the 21st Century. Toronto, Canada: 21stcentech. https:// www.21stcentech.com/agriculture-new-technologiesfood-security-21st-century/. Дата обращения 25.01.2021.

26. Start, D. (2005). Rural Diversification: What hope for the poor? Journal of development studies, 9(6), 937-970. http://citeseerx.ist.psu.edu/viewdoc/ $\underline{\text { summary?doi }=10.1 .1 .613 .5632}$ Дата обращения 20.02.2021.

\section{References}

1. Akimbekova, Ch.U.(2021). Problemy i perspektivy kazahstanskogo sela $\mathrm{v}$ uslovijah razvitija sel'skih territorij. Oficial'nyj sajt kazahstanskoj sel'skohozjajstvennoj gazety "Agrarij Kazahstana», 7(117), 6-7. http://abkaz.kz/problemy-i-perspektivykazaxstanskogo-sela-v-usloviyax-razvitiya-selskixterritorij/.Accessed date 23.07.2021.

2. Bulhairova, Zh.S. (2013). Ustojchivoe razvitie sel'skih territorij Kazahstana. Lap Lambert Academic Publishing, 272. Accessed date 10.05.21.

3. Sigarev, M.I., Palagina, I.A. (2013). Formirovanie mehanizma ustojchivogo razvitija sel'skih territorij Kazahstana. KazJeU habarshysy, 3, 15-20.

4. Kulakova, S.V. (2021). Aspekty ustojchivogo razvitija sel'skih territorij Respubliki Kazahstan. Cheboksary: ID «Sreda». Jekonomika i pravo, 22-37.

5. Kalykova, B. (2020). Rural Territories of Kazakhstan: Realities, Problems and Solutions. Problems of AgriMarket, 3, 209-215. https://doi. org/10.46666/2020.2708-9991.26
6. An official website of the International Labour Organization (ILO). Economic Diversification of the Rural Economy. https://www.ilo.org/global/topics/ economic-and-social-development/rural-development/ WCMS 437176/lang--en/index.htm. Accessed date 27.01.2021.

7.Oxford English Dictionary. $\underline{\text { http:// }}$ oxforddictionaries.com Oxford English Dictionary. http://oxforddictionaries.com. Accessed date 23.12.2020.

8. Byk, F.L., Kitushin, V.G. (2008). Konceptual'naya model' upravleniya razvitiem. Menedzhment v Rossii i za rubezhom, 6,12-19.

9. Bellù, L.G..Development and Development Paradigms A (Reasoned) Review of Prevailing Visions. Food and Agriculture Organization of the United Nations, Rome. Accessed date 13.01.2021.

10. Pearson, P. D., Roehler, L.R., Dole, J.A., Duffy, G.G. (1992). Developing expertise in reading comprehension. In S.J. Samuels \& A.E. Farstrup (Eds.), What Research Has to Say About Reading Instruction (2nd ed., pp. 145-199). Newark, DE: International Reading Association.

https://www.researchgate.net/publication/313196587 Developing_expertise_in_reading_comprehension. Accessed date 11.01.2021.

11. Sorokina, N. Yu. (2013). Kontseptualnaya model ustoychivogo razvitiya regiona. Region, 3-4, 2227.

12. Feldman, M., Hadjimichael, T., Lanahan, L., Kemeny, T. (2016). The logic of economic development: a definition and model for investment. Environment and Planning C: Government and Policy. 34, 5-21. doi: 10.1177/0263774X15614653

13. Molina, J.P. (2010). Keys for rural territorial development. Agron. Colomb., 28(3). https:// revistas.unal.edu.co/index.php/agrocol/article/ view/15313/28810. Дата обращения 18.01.2021

14. Starodubrovskaya, I. V. (2010). Problemyi selskogo razvitiya $v$ usloviyah munitsipalnoy reformyi $v$ Rossii. M.: In-t Gaydara, 116.

https://w w w.iep.ru/files/ReP Ec/gai/ rpaper/69Starodubrovskaya.pdf. Accessed date 11.12.2020

15. De Janvry, A., Sadoulet, E. (2007). Toward a territorial approach to rural development. Journal of Agricultural and Development Economics, 4(1), 6698. http://www.fao.org/3/a-ai192e.pdf. Accessed date 14.01.2021.

16. Gallardo-Cobos, R.. (2010). Rural development in the European Union: the concept and the policy. Bogotá:Agron. Colomb, 28(3). http://www.scielo.org. co/scielo.php?script=sci. Accessed date 09.01.2021

17. van der Ploeg, J. D., Renting, H., Brunori, G., Knickel, K., Mannion, J., \& Marsden, T. (2000). Rural Development: From Practices and Policies towards Theory// Sociologia Ruralis. - 2000. - № 40(4). - P. 391-408. https://doi.org/10.1111/1467-9523.00156.

18. Schejtman, A., Berdegué, J.A. (2004). Rural Territorial Development, 67.

https://www.rimisp.org/wp-content/files mf/13663830272004 schejtman berdegue rural territorial development.pdf.Accessed date $11 . \overline{0} 2.202 \overline{1}$ 


\section{REGIONAL ECONOMY AND TERRITORIAL DEVELOPMENT}

19. Porter, M.E. (1998). Clusters and the new economics of competition. Harvard Business Review, November-December, 77-90. http://backonline.apswiss. $\mathrm{ch} / 6001 /$ porter clusters and the new economics of competition.pdf. Accessed date $\overline{0} 8.02 .2021$

20. Hodge, I; Midmore, P. (2008). Models of Rural Development and Approaches To Analysis Evaluation And Decision-Making. Économie rurale Agricultures, alimentations, territoires,307. http:// journals.openedition.org/economierurale/406. Accessed date 11.01 .2021

21. An official website of the European Union. Rural development programmes per country. ec.europa. eu/info/food-farming-fisheries/key-policies/commonagricultural-policy/rural-development/country. Accessed date 27.12.2020.

22. Abuiyada, R. (2018). Traditional Development Theories have failed to Address the Needs of the majority of People at Grassroots Levels with Reference to GAD. International Journal of Business and Social Science, 9(9). doi:10.30845/ijbss.v9n9p12.
23. Abyu, G. Y. (2020). Concept of Development. Bahir Dar University, doi: 10.13140/ RG.2.2.24951.16800 Available from:

https://www.researchgate.net/publication/340127781 Concept of Development/. Accessed date 20.02.2021.

24. Francois, J., Josling, T., Raney, T., Stringer, R., Deuss, A., Skoet, J., Martin, W. (2005). The State of Food and Agriculture. Agricultural trade and poverty Can trade work for the poor? Rome: Chief Publishing Management Service Information Division. - 2005. - fao.org/3/a0050e/a0050e00.htm. Accessed date 01.03.2021.

25. Rosen, L. (2018). Agriculture Working with New Technologies to Increase Food Security in the 21st Century. Toronto, Canada: 21stcentech. https:// www.21stcentech.com/agriculture-new-technologiesfood-security-21st-century/. Accessed date 25.01.2021.

26. Start, D. (2005). Rural Diversification: What hope for the poor? Journal of development studies, 9(6), 937-970. http://citeseerx.ist.psu.edu/ viewdoc/summary?doi=10.1.1.613.5632 Accessed date 20.02.2021.

\section{Information about the authors}

Azimkhan A. Satybaldin - Doctor of Economics, Professor, Academician of the National Academy of Sciences of the Republic of Kazakhstan, Institute of Economics of the Science Committee of the Ministry of Education and Science of the Republic of Kazakhstan, Director of the State Enterprise, e-mail: ieconomkz@gmail.com, ORCID ID: https:// orcid.org/ 0000-0001-7421-4472.

* Aizhan T. Tleuberdinova - Doctor of Economic Sciences, Institute of Economics Science Committee of the Ministry of Education of the Republic of Kazakhstan, Chief Researcher, e-mail: tat404@mail.ru, ORCID ID: https:// orcid.org/0000-0001-8762-5932.

Xeniya V. Kulik - TURAN University, Republic of Kazakhstan, 1st year doctoral student, EP «Economics», +77017478659, e-mail: kulxevi2020@gmail.com, ORCID ID: https://orcid.org/ 0000-0002-3736-2078.

\section{Авторлар туралы мәліметтер}

Сатыбалдин Әзімхан Әбілқайырұлы - Экономика ғылымдарының докторы, профессор, ҚР ҰҒА академигі, Қазақстан Республикасы Білім және ғылым министрлігі Ғылым комитетінің Экономика институты, Қазақстан, директоры, e-mail: ieconomkz@gmail.com, ORCID ID: https://orcid.org/0000-0001-7421-4472.

\footnotetext{
* Тлеубердинова Айжан Тохтаровна - экономика ғылымдарының докторы, Қазақстан Республикасы Білім және ғылым министрлігі Ғылым комитетінің Экономика институты, бас ғылыми қызметкері, e-mail: tat404@ mail.ru. ORCID ID: https://orcid.org/0000-0001-8762-5932.
}

Кулик Ксения Викторовна - Тұран университетінің, Қазақстан, 1 курс докторанты «Экономика» мамандығы, +7701747865, e-mail: kulxevi2020@gmail.com. ORCID ID: https://orcid.org/ 0000-0002-3736-2078. 


\section{Сведения об авторах}

Сатыбалдин Азимхан Абилхаирович - доктор экономических наук, профессор, академик НАН РК, Институт экономики Комитета науки Министерства образования и науки Республики Казахстан, директор, е-таil: ieconomkz@gmail.com. ORCID ID: https://orcid.org/ 0000-0001-7421-4472.

* Тлеубердинова Айжан Тохтаровна - доктор экономических наук, Институт экономики Комитета науки Министерства образования и науки Республики Казахстан, главный научный сотрудник, e-mail: tat404@mail. ru. ORCID ID: https://orcid.org/ 0000-0001-8762-5932.

Кулик Ксения Викторовна - университет Туран, Казахстан, докторант 1 курса по спец-сти «Экономика», e-mail: kulxevi2020@gmail.com. ORCID ID: https://orcid.org/0000-0002-3736-2078. 